\title{
A Delphi Study to Identify Corporate Social Responsibility Indicators: The Case of Greek Telecommunication Sector
}

\author{
Grigoris Giannarakis (Corresponding author) \\ PhD Candidate - University of the Aegean, Department of Shipping Trade and Transport, Greece \\ Tel: 30-227-103-5200 Fax: 30-227-103-5229Ｅ-mail: ggianaris@aegean.gr
}

Nikolaos Litinas

Professor - University of the Aegean, Department of Shipping Trade and Transport, Greece

Ioannis Theotokas

Assistant Professor - University of the Aegean, Department of Shipping Trade and Transport, Greece

Received: December 10, 2010

Accepted: January 10, 2011

doi:10.5539/jsd.v4n2p16

\begin{abstract}
The Telecommunication sector deals with numerous social and operational challenges such as technological development, increased demand for telecommunication services, health concerns and environment protection. The aim of this paper is to identify both general and sector-specific indicators in order to measure the Corporate Social Responsibility (CSR) performance. The Telecommunication sector has analyzed and identified the main stakeholders that affect and are affected by business operations. Six main stakeholders, namely suppliers, customers, corporate governance, environment, society and human resources and forty three indicators are indentified concentrating on the Greek market with the use of Delphi technique. Additionally, the study presents a specific formula for each indicator so as to measure CSR performance in specific terms. The contribution of the study is to formulate an aggregate CSR index and translate CSR concerns into specific indicators and to recommend a methodology in order to propose indicators applicable to any sector.
\end{abstract}

Keywords: Corporate social responsibility, Telecommunication, Delphi

\section{Introduction}

The main motive for the integration of CSR standards by companies is firm's survival, economic performance and competitive advantage (Mitchell et al., 1997; Werther and Chandler, 2005). Frankental (2001) mentions that "CSR is a vague and intangible term which can mean anything to anybody, and therefore is effectively without meaning". The main concept of the CSR is the satisfaction of the stakeholders' expectations beyond the obligation of the law. Carroll (2000) supports that CSR is a multi-construct model that companies should concentrate on multiple stakeholders and not only on one type based on "if we do less than this, we should not call it social performance". The last two decades, CSR measuring has garnered significant interest from Social Responsible Investment (SRI) indexes and organizations such as Dow Jones Sustainable index (DJSI), KLD, EIRIS and United Nations. Generally, there are four approaches in the measurement of CSR performance: corporate reputation indices, analysis of the contents of annual reports/publications, perceptual measurements which derive from questionnaire-based surveys and single-and multiple-issue indicators (Igalens and Gond, 2005; Turker, 2009; Maignan and Ferrell, 2000).

The majority of the methodologies that measures CSR include indicators that do not take into account the direct or indirect effects of each sector. It is unfair to measure the CSR performance sectors since they have different operational activities and different stakeholders' impact with the same indicators. The study concentrates on the telecommunication sector proposing multiple-issue indicators while the Delphi method is adopted in order to recommend both general and sector-specific CSR indicators. The Telecommunication sector is selected because the extensive use of telecommunication services in Greece, the health and environmental concerns are always in public debate and the telecommunication sector plays an important role to economy of Greece, businesses and personal lives. Finally, it is appropriate and highly related to CSR analysis since the companies integrate CSR values into their operations. This study excludes financial components that are directly connected to the 
shareholder profit, while it incorporates the stakeholder approach. The paper contributes to literature in several ways:

- proposes general and sector-specific indicators relevant to and tailored for the sector of telecommunication formulating a CSR aggregate index,

- proposes a specific formula for each indicator in order to measure the CSR performance in specific terms,

- attempts to standardize and start a debate as regards sector specific indicators for the telecommunication sector,

- recommends a comprehensive methodology in order to propose CSR indicators that could be adapted to every sector using Delphi method.

The literature review of telecommunication sector social concerns is presented along with the necessity of sector-specific indicators followed by the methodology. In section 4, the results are analyzed and, finally, a discussion of the findings is provided in section 5 .

\section{Literature review}

\subsection{Telecommunication sector concerns}

This section presents and analyzes the main CSR concerns of the telecommunication sector such as environment, health, digital divide and privacy. It is obvious that the content of concerns is unique or highly related to the telecommunication operators. However, there are many other direct or indirect concerns such as employee satisfaction and dematerialization (Runhaar and Lafferty, 2009; Lafferty, 2006). A significant source of information for the identification of essential issues concerning CSR and telecommunication sector is the Information Communication Technology (ICT).

\subsubsection{Environmental concerns}

According to European Telecommunication Network Operators' Association (ETNO) (2005), energy consumption is considered as the largest environmental impact of the companies because the telecommunications networks need large amounts of electrical energy increasing related emissions while there are telecommunication products that never switch off, known as "stand-by mode" (Knast, 2005). Not only do "servers" need to work constantly but also new devices and services demand more energy. Similarly, the World Summit on the Information Society (2002) states that the ICT consumes $5 \%$ and $10 \%$ of the total electricity demand in the industrialized countries while it is responsible for the $1 \%-3 \%$ to worldwide $\mathrm{CO}_{2}$ emissions. Only the Deutsche Telekom consumes approximately $0.5 \%$ of the total German energy consumption revealing that renewable resources are essential (James and Hills, 2003). Another effect is that many devices contain hazardous materials that could cause several environmental problems, for example, the mobile telephones' batteries contain toxic metals or cathode ray tubes contain lead. Additionally, there is a debate as to whether ICT increases or reduces the need for travel. On the one hand, e-commerce, teleworking and telematics reduce the travel need or shorten the journeys decreasing the impact on the environment. On the other hand, more deliveries, geographically longer supply chains and rebound effects increase the harmful impact on the environment. The electronic management waste without damaging the natural environment is another major challenge. The constant demand for new ICT technologies leads to shorten technology cycles (Plepys, 2002). Similarly, European Information Technology Observatory (EITO) (2002) mentions that obsolete or undesirable products are increasing because of the rapid technological development. The ICT companies can contribute to business sustainable development adopting lower-power technology (WSIS, 2003), responsible infrastructure and increase recycling or reusing of redundant ICT devices.

\subsubsection{Health concerns}

One of the potential threats to telecommunication sector is the electromagnetic fields (EMF) (ETNO, 2005; Arnfalk, 2002) not only to the general public but also to the employees who work in telecommunication companies. Until now, thousands of surveys regarding the hazard of EMF (Greek Atomic Energy Commission) have been conducted, more than those conducted on any chemical factor. All relevant studies conclude that the RF fields do not cause adverse health consequences, (World Health Organization, 2000). A more recent study of World Health Organization (2004) mentions that even if numerous of scientific researches into this field exist, there is no evidence that non-ionizing radiation affects the human health. The International Commission for Non-ionizing Radiation Protection (ICNIRP) is based only on science excluding social and economical factors in order to propose safe guidelines against any adverse effect established (Vecchia, 2007). Directive 2004/40/EC (2007) refers to the minimum health and safety requirements as regards the exposure to electromagnetic fields. It 
should be mentioned that both ICNIRP and World Health Organization revise the criteria and limit values for low-frequency fields adopting the new studies (European Commission, 2007).

\subsubsection{Digital divide}

The concept of digital divide refers to the gap between those who have accessibility to ICT such as telephones, computers, internet and related services and to those without. The term is used in an international or global level and within a country or region or other reference entity such as income, gender, age and educational level (Lambrou, 2006; Ani, 2007; United Nations, 2006). James and Hills (2003) define the digital divide as "differences in the use of, and access to, information and communication technology (ICT) tools, and particularly the internet" mentioning that the accessibility to ICT is greater in rich countries than the poor ones. Klecun (2008) suggests that many groups such as local authorities, educators, technology designers and pressure groups could act in order to eliminate the digital exclusion, for example, a government could fund the ICT infrastructures, ICT centers and courses in remote areas. Cullen (2001) and Salinas (2003) mention some of the barriers of using the internet such as lack of physical access to ICTs, skills and support, relevant content and negative attitudes. The most important hindrance for ICT accessibility is economic (Kim and Kim, 2001; Hubregtse, 2005) while other hindrances are the exponential property of information and socio-demographic factors such as age and education (Abbey and Hyde, 2009). According to WSIS (2003), all governments declare that the elimination of the digital divide is one of the priorities of this millennium with developed economies having lower gaps of digital divide than developing ones (Mutula, 2008). EITO (2002) states that multinational ICT companies spend a lot of money on the decrease of digital divide, for example, an ICT equipment manufacturer spends over $€ 1$ billion worth of its products on developing countries.

\subsubsection{Privacy}

The protection of the privacy is in focus of ICT sector. Despite the various benefits from the telecommunication services the privacy remains a major concern among general public, business, institutions, organizations and governments. The term privacy concerns the protection of personal information and transmitted data (Chen et al. 2008). In the European Union, the protection of the personal data in the electronic communication sector is determined by the EU Data Protection Directive (1995) which stops the transfer of personal information from European Union to U.S. The personal data is in danger from inside and outside parts of telecommunication companies (European Communities, 2002). Yehle (1996) states that employees from a telephone company used customers' data for illegal reasons. The privacy and the security of telephone interactions have become a priority of the general public and other social parties in Greece as the telephone interception of the political parties has taken great dimensions. The telecommunication companies support that external factors are responsible for the interception.

Regarding the internet communication where the exchange of information is easy, spam, commercial email and cookie technology are another type of privacy invasion (Castaneda et al., 2007; Ho, 1999), thus it is important for companies to develop any kind of technology with cautiousness (Argandona, 2003). Some of the proposed actions in order to protect the privacy are encryption, digital signing and Privacy Protector (PP) software entity (Gritzalis, 2004; Vaccaro, 2006). In addition, telecommunication companies could be committed to projects for a new technology in order to protect the consumers' data more effectively. They could inform the consumers on what is the legitimacy as regards the stored data, for example, those who have accessibility in the stored data (Wright, 2005). Firms in the field of CSR could inform their customers on how and for how long they store personal information (Chen et al. 2008) or when companies intend to sell data personal information (Kruck, 2002) as they have at their disposal accurate consumers' data (Vaccaro, 2006). ). The adoption of pseudonymous or anonymity of customers is considered a chance for the development of e-commerce (Christopherson, 2007). However, there are cases where there is a will to sacrifice the privacy right for security reasons especially after the terrorist incident on $11^{\text {th }}$ September in 2001 (Wright, 2005).

\subsection{Necessity of sector-specific indicators}

Two main approaches appear in order to measure and assess CSR. The first approach considers general indicators independent of which sector the company belongs to. The general approach does not consider the direct and indirect effects of its sector in society (Graafland et al., 2003, 2004; Hino, 2001). As regards the second approach, it proposes both general and specific indicators, counting the direct and indirect effects of each sector. The D.J.S.I family indexes include in their methodology not only core but also sector-specific indicators, counting the special characteristics of 58 sectors. The Global Reporting Initiative (GRI) (2007) develops a sustainable reporting framework which contains both generic and sector-specific industry indicators, receiving the specific characteristics of each industry such as telecommunications. Azapagic and Perdan (2000) mention 
the necessity for both generic and sector-specific indicators in their sustainable framework. Azapagic (2003) proposes compatible with the GRI general indicators for the mining and mineral industry. Mudzamir and Norfaiezah (2007) investigate the concentration of CSR initiatives on mobile telecommunication companies in Malaysia while Talaei and Nejati (2008) propose 33 general and specific indicators in order to assess the CRS of companies that operate in auto industry of Iran covering economic, legal, ethical and altruistic stakeholder's categories. Sachs et al. (2006) examine a Swiss mobile telecommunication provider investigating the CSR for the employees and giving examples of principles and performance indicators of Orange Communications. Secchi (2006) supports the necessity to take into account the sector where companies operate in the measurement procedure and proposes a model in order to classify the CSR commitment in three dimensions: sector, size and country-specific issues. Sturdivant and Ginter (1977) support that CSR should be studied at industry field and Simpson and Kohers (2002) concentrate on the banking sector, suggesting social indicators which are unique to the sector. Sweeney and Coughlan (2008) investigate the primary and secondary stakeholders of 30 firms, studying the CSR reports, concluding that it is difficult to understand CSR because there are differences on how each company from different sector conceptualizes CSR relative to their stakeholders. Patten (1991) concludes that the industry is a significant factor influencing CSR disclosure. Bichta (2003) mentions that in the field of CSR the environmental policy and performance are affected by the sector that companies operate. Griffin and Mahon (1977) claim that each sector confronts different social pressures criticizing the cross-sectional analysis contrary to Graafland et al. $(2003,2004)$ and SRI indexes methodologies. Aravossis et al. (2006) propose a CSR framework that contains unique characteristics for each sector and company and Van Dijken (2007) mentions that CSR actions depend on sector characteristics, more specifically "given a limited amount of resources (from staff, time or cash), different companies, in different sectors, will prioritize different stakeholders". Knox and Maklan (2004) indicate that companies deny standardizing their reports because they are not suitable for their own industry or firm and, additionally, their CSR activities should be relevant to the industry they operate. Finally, a company's priorities in the field of CSR depend on the sector that the company operates (Dawkins and Lewis, 2003).

A more careful investigation is needed in order to judge the companies' real impact on the stakeholders. It is obvious that the telecommunication companies should reflect the environmental and social impacts of their products and services on their CSR activities.

\section{Methodology}

\subsection{Research description}

The concept of CSR is characterized as complex, vague, with inexplicit boundaries and board, devoid of consensus regarding CSR categories and indicators. The Delphi method is adopted because it allows the respondents to revaluate their answers (Grisham, 2009) proposing general and sector-specific indicators for the Greek telecommunication sector with cautiousness. Predicated on the logic that "two heads are better than one" (Dalkey, 1972), Delphi method is developed to reach a consensus from an expert panel for a complex problem where knowledge is limited (Williams and Webb, 1994, Hauck et al., 2007; Phillips, 2000; Dalkey and Helmer, 1963; Linstone and Turoff, 1975). The Delphi methodology can be used for a plethora of cases, such as sustainable tourism (Miller, 2001; Choi and Sirakaya, 2006), CSR (Hussein, 2010; Talaei and Nejati, 2008), human resources development (McGuire and Cseh, 2006), government planning (Linstone and Turroff, 2002), environmental management (Gokhale, 2001), medicine (Efstathiou et al., 2008; Keeney et al., 2001) and strategic management (Loo, 2002), while it is applied to select performance indicators in several fields (Ma et al., 2011). Typically, Delphi methodology involves expert panel, repeated rounds, opportunity for respondents to reconsider their responses and finally, anonymity of the expert panel.

\subsubsection{Expert panel}

Delphi technique incorporates an iterative survey of experts (Huge et al., 2010). There is no agreement on what an expert is, as different definitions are proposed (Keeney et al., 2001; Baker et al., 2006) and whatever definition is given seems arbitrary (Goodman, 1987). Many authors propose an appropriate size of expert panel varying from a few to a few hundred experts (Cavalli-Sforza and Ortolano, 1984; Wild and Torgersen, 2000; Skulmoski et al. 2007). However, there is no standard number of experts (Williams and Webb, 1994) as it depends on the nature of the problem (Powell, 2003). In the case of this study, the companies' executives from the CSR departments or Communication departments, when CSR department does not exist, are selected for two main reasons. On the one hand, CSR is a concept arisen by companies, CSR executives can perceive the needs of stakeholders better than other types of experts and the personal experience of companies' executives could be considered as an important criterion for their selection (Loo, 2002). On the other hand, in Greece the concept of 
CSR is not well developed, the experts for CSR are limited and their judgment would not be reliable because the telecommunication sector is distinguished for its unique CSR characteristics. Additionally, the CSR experts outside the company have higher expectations standards than other stakeholders or experts (Dawkins, 2004).

\subsubsection{Repeated Rounds}

Another characteristic of the method is the sequential rounds of questionnaires. The majority of studies include open-ended questions formulating the initial questionnaire in the first round, which is the base for the second round, and ask the expert panel to comment on the issues (Thangaretinam and Redman, 2005; Chu and Hwang, 2008). However, Hsu and Sandford (2007) support that the first round can be based on extensive literature review. In the second round and the subsequent ones, specific items are ranked or assessed by criteria of significance. In this study, three rounds of Delphi survey are conducted (Green et al., 1990; Turoff, 1970; Thangaretinam and Redman, 2005; Delbecg et al., 1975; Linstone and Turoff, 1975; Bowles, 1999) and each round is based on the results of the previous ones (Sumsion, 1998).

Round 1: The first round is based on literature review, thus, four sources are indentified in order to distinguish the most import stakeholders:

telecommunication companies, methodologies by SRI indexes,

authors and international organizations

As regards the first source which is the base for the stakeholders' categorization, the annual CSR reports of Greek and European foreign telecommunication companies are taken into account. The authors attempt to suggest a limited number of indicators covering the most important aspects of CSR for reasons of simplicity. There are Greek companies that are not included in the categorisation process as they do not publish CSR report or they do not follow a multiple approach in CSR field. The content of CSR reports is used in order to ascertain how the companies implement CSR (Sweeney and Coughlan, 2008).

Round 2: The experts in the second round are asked to rank the importance of indicators of each stakeholder from the most to the least important and select the most important sub-indicators, in case this option exists. At this round, experts are able to generate additional indicators that are not probably taken into account in the first round and to exclude not appropriate indicators.

Round Three: Two weeks later, all indicators and stakeholder categories are sent to experts in order to reconsider the proposed value placed in the second round providing them with their previous rank order, the mean value and the standard deviation of the other experts.

\subsubsection{Anonymity of the expert panel}

Finally, anonymity of the responds is preserved in order to secure honest expression and avoid open debate and dominance or confrontation among the experts. Additionally, anonymity ensures accurate results (Franklin and Hart, 2007; Charlton et al., 1981; Wolfers and Zitzwitz, 2004; Goodman, 1987). The term "quasi anonymity" is more appropriate as only the researchers are aware of the expert panel (McKenna, 1994) and none of the expert panel knows the judgment of the others.

\subsection{Research limitations}

There are 22 companies that are providers of fixed-mobile telephony and internet access in the Greek market. However, the questionnaires were sent to 17 companies because of acquisitions that have been made in the telecommunication sector during the last years. Eight companies-experts responded giving an approximate 47 percent response rate. All eight companies are fixed telephony providers; two of them provide mobile telephony services and seven companies offer internet access services. A two - step approach is followed by the authors in order to communicate with companies, that is, a pre-notification letter describing the aim of the study and the reasons for their selection and a cover letter with the questionnaire (Blumberg et al. 1974; Cavusgil and Elvey-Kirk, 1998).

\section{Research results}

The results of the three rounds are presented in this section.

Round 1: The literature review concludes that CSR is a multiple construct. Table 1 presents the identified stakeholders that are recommended by the four different types of sources. The authors imply that the category of suppliers is considered beyond the company's responsibility, probably, because their monitor is very difficult mostly when the structure of supply chains shift. All telecommunication companies agree that the six identified 
stakeholders should be included in a CSR framework. The stakeholders of environment, human resources and society are highly mentioned by all sources. The six proposed CSR categories can be considered strategic and generic for all types of sectors even if some of the sources of information are concentrated on the telecommunication sector.

\section{Insert Table 1.}

In table 2, there is a presentation of the indicators identified from 15 both Greek and European foreign telecommunication companies. Totally, 43 indicators are identified from the annual CSR reports of the telecommunication companies. The categories of corporate governance and society are split in two sub-categories.

\section{Insert Table 2.}

A value tree for the CSR aggregate index, which constitutes six domains of stakeholders and two sub-categories, is formulated, Figure 1.

\section{Insert Figure 1.}

Round 2 and 3: Eight experts rank the importance of each indicator according to their perception, while in some cases, companies select the most important sub-indicator. The number of experts committed to the survey is acceptable for the Delphi methodology (Linstone, 1978; Cantrill et al., 1996; Phillips, 2000). In the next tables, the statistical data for each identified category and indicator are presented and there is a proposed formula for each indicator. In cases there are sub-indicators, the proposed formula refers to the most preferred sub-indicator.

Regarding suppliers, the most important indicator is the criteria for the selection of a new supplier even if it has high Std. deviation showing lack of consensus, Table 3. In most of the cases, a new supplier should operate transparently and provide internal information data in order to convince that its operations standards do not affect its stakeholders. Some of the main criteria of concerns are environmental impact, health and safety issues. The collaboration with the suppliers is ranked in the second place including sub-indicators such as compatibility of suppliers' products or services standards with the Greek legislation and companies' needs or standards. In the third place of importance with small relative Std. deviation are audits that telecommunication companies conduct to suppliers taking into account numerous topics that are essential according to companies' perception. The transparent operation with suppliers such as publishing of important documents for the supply chain stands in the last place of importance.

\section{Insert Table 3.}

The responsible marketing is a part of CSR indicators that telecommunication companies consider as the most important indicator in this category, Table 4. Companies attempt to promote their products or services in a responsible and fair way. In the second place of importance, it is the service satisfaction from the personnel. The responsible technology stands in the third place of importance and contains privacy, spam protection and restriction of inappropriate content to children or juvenile and in the fourth place, it is the information for aspects relative to telecommunication services including the environmental impact and the safe use of products and services. It would be expected the quality of services to be ranked in the first places of importance because it is a very important component for the survival of the sector; however, it is ranked in the fifth place of importance. The last place concerns the number of customers' surveys conducted by the company in order to monitor the customers' perception on a regular base.

\section{Insert Table 4.}

Health and safety of the personnel in the workplace is distinguished as the first priority for the CSR in this category. The small Std. deviation indicates that there is a strong consensus regarding the importance of this indicator and includes sub-indicators such as health and safety inspection to offices, shops and networks and committees that are responsible to standardize health and safety metrics. The second most important indicator is equal opportunities of personnel or perspective one without discrimination or prejudice such as race, religion and sexual orientation. The training indicators include programs for the new products or services, for the customer's services and the professional development. In the fifth place of importance, it is the benefits to the personnel when specific predetermined goals are achieved, while in the sixth place it is the employee satisfaction from the company's environment. In the last place of importance, the indicator of flexible working programs that a company introduce is ranked. The flexible working programs in Greek telecommunication companies are ranked in the last place of importance contrary to European companies which include different programs.

\section{Insert Table 5.}


Table 6 concerns the CSR management indicators in which the most important one is the compliance with international standards or organizations such as ISO and GRI in order to manage their operations in a systematic way. In the second place, it is the differentiation of stakeholders' weight which concerns the different importance of each stakeholder, while the risk management connected to all corporate activities is ranked in the third place. The identification of stakeholders' expectations and needs is considered a very important procedure because it ensures that the CSR indicators are appropriate for companies and stakeholders (Dawkins and Lewis, 2003), though it is ranked in the fourth place of importance. The CSR concept in the decision procedure is ranked in the fifth place, while the assessment of CSR results stands in the sixth place of importance and it can be assessed either from the company or special organizations. In the last place of importance, it is the transmission of the CSR concept to suppliers or subsidiaries.

\section{Insert Table 6.}

The presentation of qualitative and quantitative data is considered the most important indicator as almost all investigated companies present or compare data in different chronological periods in their CSR reports. The publication of the non compliance with the legitimacy is ranked in the second place of importance. Almost all companies include positive CSR indicators or practices and avoid mentioning cases of the non compliance with the law. However, only one Greek company refers to cases that do not comply with the legislation. Conclusions regarding business operations and CSR indicators by stakeholders or external organization are ranked in the third place of importance.

\section{Insert Table 7.}

Companies consider philanthropy as first priority supporting minority groups of people such as the improvement of children's living conditions along with the indicator of the voluntary personnel program to social projects. The high importance of philanthropy can be explained by Useem (1988) who supports that sectors with high levels of public contact contribute more financial capital to society. In the third place of importance, it is the commitment to research project on environmental impacts, technology innovation and health and safety issues. In the fourth place, it is the dialogue with other stakeholders, while sponsorships are categorized in the last place of importance though telecommunication companies spend increased financial capital in order to sponsor sport and musical events.

\section{Insert Table 8.}

The most important indicator for companies in order to decrease the gap of digital divide is the development of infrastructure in remote or low population density areas. In the second place, it is the proper function after emergency situations and in the third place the equal access to people with special needs such as products for people with hearing and speech disabilities is ranked. Next, the education or the information concerning the advantages of telecommunication services is ranked in the fourth place and finally, in the last place stands the distribution of products or services. A company suggests a sixth indicator, namely, exploitation of technology of mobile communication for the social benefits such as telemedicine programs. However, it is not included in the list because it is very specific and ineffective to all operators.

\section{Insert Table 9.}

Regarding the domain of environment, in the first place of importance, it is the monitoring of electromagnetic radiation from telecommunication networks, while in the second place, recycling or reusing stands such as electronic and electric components and office/shop equipment. The responsible development networks is ranked in the fourth place of importance and includes sub-indicators taking into account the environmental impacts of telecommunication networks, common telecommunication infrastructure with other companies and aesthetic harmonisation of the infrastructure. In the last place, it is the indicator of energy and natural sources saving programs. Companies implement environmental programs in order to reduce the energy consumption not only in their offices and shops but also in telecommunication networks.

\section{Insert Table 10.}

\section{Conclusions}

The majority of the CSR assessment methodologies adopt general indicators without taking into account the specific challenges and trends that each sector confronts. The lack of CSR indicators for the telecommunication sector triggered the interest of authors to develop a system of CSR categories and indicators where each company could assess the CSR performance. Totally, six stakeholders are identified, namely, suppliers, corporate governance, environment, customers, society and human resources and forty three indicators are identified creating an aggregate CSR index for the Greek market. Even if CSR is a subjective, amorphous, highly 
intangible, unclear, vague, ambiguous and fuzzy concept, experts do not suggest indicators, except for one expert who proposes only one in the digital divide sub-category, implying that the proposed indicators are appropriate for the assessment of CSR performance. Additionally, there are common indicators among the Greek and European telecommunication companies that provide a consensus for the implementation of CSR in business operations. In this way, each telecommunication operator could be assisted to reflect its position in relation to its social responsibilities ascertaining its strengths and weaknesses. It is obvious that as far as social and environmental indicators are concerned there is a consensus with Turker (2009) conclusions that companies not only do they avoid to manipulate the society but also to influence it. The majority of the proposed indicators are non-financial because they are compatible with the CSR concept and SRI indexes methodologies, while the traditional financial ones are excluded as they do not ensure the success of the company in the new business era and they confront a number of challenges (Giannarakis et al. 2009; Kaplan and Norton, 1996; Bourn, 1996). However, the inclusion or not of financial indicators depends on what meaning is given to the CSR concept. A topic for future survey will be to determine the weight of each indicator and to formulate the equation in order to measure the CSR performance.

\section{References}

Abbey, R., \& Hyde, S. (2009). No country for older people? Age and the digital divide. Journal of Information, Communication \& Ethics in Society, 7, 225-242.

Ani, O.E., Uchendu, C., \& Atseye, E.U. (2007). Bridging the digital divide in Nigeria: a study of internet use in Calabar Metropolis, Nigeria. Library Management, 28, 355-365.

Aravossis, K., Panayiotou A., \& Tsousi, K. (2006). A Proposed Methodological Framework for the Evaluation of Corporate Social Responsibility. Proceedings of the 1st International Conference on Environmental Economics and Investment Assessment, Mykonos, Greece.

Argandona, A. (2003). The New Economy: Ethical Issues. Journal of Business Ethics, 44, 3-22.

Arnfalk, P. (2002). Virtual mobility and pollution prevention, the emerging role of ICT based communication in organisations and its impact on travel. Doctoral dissertation, ISBN: 91-88902-23-4, May.

Azapagic, A. (2003). Systems approach to corporate sustainability: A general management framework. Process Safety \& Environmental Protection, 81, 303-316

Azapagic, A., \& Perdan, S. (2000). Indicators of sustainable development for industry: A General Framework. Institution of Chemical Engineers Trans IChemE, 78, Part B.

Baker, J., Lovell, K., \& Harris, N. (2006). How expert are the experts? An exploration of the concept of 'expert' within Delphi panel techniques. Nurse Researcher, 14, 59-70.

Bichta, C. (2003). Corporate Socially Responsible (CSR) indicators in the context of Greek industry. Corporate Social Responsibility and Environmental Management, 10, 12-24.

Blumberg, H., Fuller, C., \& Hare, A. (1974). Response rates in postal survey. Public Opinion Quarterly, 38, 113-123.

Bourn, M.C.S. (1999). Designing and implementing a balanced performance measurement system. Control, 25, 21-24.

Bowles N. (1999). The Delphi technique. Nurs Stand, 13, 32-36.

Calvert Index. [Online] Available: www.calvert.com (3-08-2010)

Cantrill, J.A., Sibbald, B., \& Buetow, S. (1996). The Delphi and nominal group techniques in health services research. International Journal of Pharmacy Practice, 4, 67-74.

Carroll, A.B. (2000). A Commentary and an Overview of Key Questions on Corporate Social Performance Measurement. Business \& Society, 39, 466-478.

Castaneda, J.A., Montoso, F., \& Luque, T. (2007). The dimensionality of customer privacy concern on the internet. Online Information Review, 31, 420-439.

Cavalli-Sforza, V., \& Ortolano, L. (1984). Delphi forecasts of land-use - transportation interactions. Journal of Transportation Engineering, 110, 324-339.

Cavusgil, S.T., \& Elvey-Kirk, L.A. (1998). Mail Survey Response Behavior; A Conceptualization of Motivating Factors and Empirical Study. European Journal of Marketing, 32, 1165-1192.

Charlton, J.R.H., Patrick, D.L., Matthews, G., \& West, P.A. (1981). Spending priorities in Kent: a Delphi study. Journal of Epidemiology and Community Health, 35, 288-292.

Chen, J.V., Ross, W., \& Huang, S.F. (2008). Privacy, trust, and justice considerations for location-based mobile telecommunication services. Info, 10, 30-45. 
Choi, H.C., \& Sirakaya, E. (2006). Sustainability indicators for managing community tourism. Tourism Management, 27, 1274-1289.

Christopherson, K.M. (2007). The positive and negative implications of anonymity in Internet social interactions: 'on the internet, nobody knows you're a dog'. Computers in Human Behavior, 23, 3038-56.

Chu, H. C., \& Hwang, G. J. (2008). A Delphi-based approach to developing expert systems with the cooperation of multiple experts. Expert Systems with Applications, 34, 2826-2840.

Cullen, R. (2001). Addressing the digital divide. Online Information Review, 25, 311-320.

Dalkey, N., \& Helmer, O. (1963). An experimental application of the Delphi method to the use of experts. Management Science, 9, 458-67.

Dalkey, N. (1972). The Delphi method: An experimental study of group opinion. [Online] Available: www.rand.org/pubs/research_memoranda/2005/RM5888.pdf (12-08-2010)

Dawkins, J. (2004). The Expert Perspective: Views of Corporate Responsibility among NGOs and CSR Commentators, MORI.

Dawkins, J., \& Lewis, S. (2003). CSR in Stakeholder Expectations: And Their Implication for Company Strategy. Journal of Business Ethics, 44, 185-193.

Delbecg, A.L., Van de Ven, A.H., \& Gustafson, D.H. (1975). Group techniques for program planning. Glenview, IL: Scott, Foresman.

Dow Jones Sustainability Index (DJSI). [Online] Available: www.sustainability-index.com (9-09-2010)

Efstathiou, N., Ameen, J., \& Coll, A.M. (2008). A Delphi study to identify healthcare users' priorities for cancer care in Greece. European Journal of Oncology Nursing, 12, 362-371.

Ethibel Sustainable Index. [Online] Available: www.ethibel.org (17-10-2010)

Ethos institute. [Online] Available: www.ethos.org.br (20-09-2010)

European Commission. (2001). Green Paper: Promoting a European framework for Corporate Social Responsibility. Brussels.

European Commission. (2007). DIRECTIVE OF THE EUROPEAN PARLIAMENT AND OF THE COUNCIL amending Directive 2004/40/EC on minimum health and safety requirements regarding the exposure of workers to the risks arising from physical agents (electromagnetic fields) (eighteenth individual Directive within the meaning of Article 16(1) of Directive 89/391/EEC)", COM(2007) 669 final, Brussels.

European Communities. (2002). DIRECTIVE 2002/58/EC OF THE EUROPEAN PARLIAMENT AND OF THE COUNCIL of 12 July 2002 concerning the processing of personal data and the protection of privacy in the electronic communications sector (Directive on privacy and electronic communications). Available at: http://eur-lex.europa.eu/pri/en/oj/dat/2002/1_201/1_2012002073 1en00370047.pdf (23-11-2010)

European Information Technology Observatory (EITO), (2002), The impact of ICT on sustainable development. [Online] Available: www.digital-eu.org/uploadstore/eito_forum_2002.pdf (16-10-2010)

European Telecommunications Network Operators' Association (ETNO) (2005), Accountability in Connectivity - ETNO Environmental Report. [Online] Available: www.etno.be/Portals/34/publications/other/ETNO\%20environmental\%20report\%202005.pdf (10-11-2010)

Frankental, P. (2001). Corporate Social Responsibility-A PR Invention. Corporate Communications: An International Journal, 6, 18-23.

Franklin, K.K., \& Hart, J.K. (2007). Idea generation and exploration: Benefits and limitations of the policy Delphi research method. Innovative Higher Education, 31, 237-246.

Giannarakis, G., Litinas N., \& Theotokas, I. (2009). Characteristics of Corporate Social Responsibility indicators. International Conference on Business, Economics, Management and Marketing, Paris, France.

Global Reporting Initiative (GRI). (2007). The GRI's Sustainability Report July 2004 - June 2007. [Online] Available:www.globalreporting.org/NR/rdonlyres/43127B6A-3816-406C-897F-AC572E0EAB2D/0/GRI_SR_2 0042007.pdf (1-11-2010)

Gokhale, A.A. (2001). Environmental initiative prioritization with Delphi approach: a case study. Environmental Management, 28, 187-193.

Goodman, C. (1987). The Delphi technique: a critique. Journal of Advanced Nursing, 12, 729-734.

Graafland, J.J., Eijffinger S.C.W., \& Smid, H. (2004). Benchmarking of Corporate Social Responsibility: Methodological Problems and Robustness. Journal of Business Ethics, 53, 137-152.

Graafland, J.J., Eijffinger, S.C.W., Stoffele, N.C.G.M., Smid, H., \& Coldeweijer, A.M. (2003). Corporate social responsibility of Dutch companies: Benchmarking and Transparency. De Economist, 152, 403-426.

Greek Atomic Energy Commission. [Online] Available: www.gaec.gr (26-10-2010) 
Green, H., Hunter, C., \& Moore, B. (1990). Assessing the environmental impact of tourism development; using the Delphi technique. Tourism Management, 11, 111-120.

Griffin, J., \& Mahon, F. (1997). The corporate social performance and corporate financial performance debate: Twenty-five years of incomparable research. Business and Society, 36, 5-32.

Grisham, T. (2009). The Delphi technique: a method for testing complex and multifaceted topics. International Journal of Managing Projects in Business, 2, 112-130

Gritzalis, D. (2004). Embedding privacy in IT applications development. Information Management \& Computer Security, 12, 8-26.

Hauck, Y., Kelly, R.G., \& Fenwick, J. (2007). Research priorities for parenting and child health: a Delphi study. Journal of Advanced Nursing, 59, 129-139.

Hino, K. (2006). Corporate Social and Financial Performance: An Empirical Study on a Japanese Company. IFSAM VIIIth World Congress, September 28-30, Berlin, Germany

Ho, D. (1999). Pass me a cookie, please ... or not!. SiliconIndia, August.

Hsu, C.C., \& Sandford, B.A. (2007). The Delphi technique: Making sense of consensus. Practical Assessment. Research \& Evaluation, 12, 1-8.

Hubregtse, S. (2005). The digital divide within the European Union. New Library World, 106, 164-172

Huge, J., Trinh, H.L., Hai, P.H., Kuilman, J., \& Hens, L. (2010). Sustainability indicators for clean development mechanism projects in Vietnam, Environ Dev Sustain, 12, 561-571.

Hussein, M.M. (2010). Corporate social responsibility: finding the middle ground. SOCIAL RESPONSIBILITY JOURNAL, 6, 420-432.

Igalens, J., \& Gond, J.P. (2005). Measuring Corporate Social Performance in France: A Critical and Empirical Analysis of ARESE data. Journal of Business Ethics, 56, 131-148.

James, P., \& Hills, S. (2003). A sustainable E-Europe: Can ICT Create Economic, Social and Environmental Value, SustainIT. UK Center for Economic and Environmental Development. [Online] Available: www.sustainit.org/publications/files/32-Sustainablee-Europe-Finalreport.pdf (10-10-2010)

Jantzi Social Index. [Online] Available: www.jantzisocialindex.com (20-11-2010)

JSE SRI Index. [Online] Available: www.jse.co.za/sri (29-10-2010)

Kaplan, R.S. and Norton, D.P. (1996). The Balanced Scorecard - Translating Strategy into Action. Harvard Business School Press, Boston, MA.

Keeney, S., Hasson, F., \& McKenna, H.P. (2001). A critical review of the Delphi technique as a research methodology for nursing. International Journal of Nursing Studies, 38, 195-200.

Kim, M.C., \& Kim, J.K. (2001). Digital Divide: Conceptual Discussions and Prospect, The Human Society and the Internet Internet-Related Socio-Economic Issues. Springer Berlin / Heidelberg.

Klecun, E. (2008). Bringing lost sheep into the fold: questioning the discourse of the digital divide. Information Technology \& People, 21, 267-282.

Knast, J. (2005). Assessing Opportunities for ICT to Contribute to Sustainable Development, Developed for the DG Information Society of the European Commission. [Online] available at: http: ec.europa.eu/ dgs/information_society/evaluation/data/pdf/studies/r2005_1/ictsus_final.pdf (17-10-2010)

Knox, S., \& Maklan, S. (2004). Corporate Social Responsibility: Moving Beyond Investment Towards Measuring Outcomes. European Management Journal, 22, 508-516.

Kruck, S.E, Gottovi, D., Moghadami, F., Broom, R., \& Forcht, K.A, (2002). Protecting personal privacy on the internet. Information Management \& Computer Security, 10, 77-84.

Lafferty, H. (2006). Corporate Social Responsibility in the Telecommunications Industry. An Assessment of CSR Strategies and the Role of the UN Global Compact. Master Thesis (Sustainable Development Master Programme), Utrecht University, Utrecht. [Online] Available: www.sum.uio.no/publications/pdf_fulltekst/prosusrep2006_03.pdf(12-11-2010)

Lambrou, M. (2006). REFLECTIONS ON DIGITAL, CSR-AWARE SHIPPING. International Conference Shipping in the era of Social Responsibility, Argostoli, Cephalonia, Greece.

Linstone H.A. and Turoff M. (2002). General applications: introduction. In The Delphi Approach: Techniques and Applications. In Turoff M, Linstone HA (eds). Addison-Wesley Publishing Company Inc.: Reading, MA; 71-79. [Online] Available: www.is.njit.edu/pubs/delphibook (15-12-2010)

Linstone, H.A. (1978). The Delphi technique. In Fowles, R.B. (Ed.), Handbook of Futures Research, Greenwood, Westport, CT, pp. 271-300. 
Linstone, H.A. and Turoff, M. (1975). The Delphi method: Techniques and applications. Reading, MA: Addison Wesley Publishing.

Loo, R. (2002).The Delphi method: a powerful tool for strategic management. Policing: An international Journal of Police Strategies \& Management, 25, 762-769.

Ma, Z., Shao, C., Ma, S., \& Ye, Z. (2011). Constructing road safety performance indicators using Fuzzy Delphi Method and Grey Delphi Method. Expert Systems with Applications, 38, 1509-1514.

Maala Index. [Online] Available: www.maala.org.il/eng/tools/index/01/default.asp?ContentID=338 (14-12-2010)

Maignan, I., \& Ferrell, O.C. (2000). Measuring Corporate Citizenship in Two Countries: The Case of the United States and France. Journal of Business Ethics, 23, 283-297.

McGuire, D., \& Cseh, M. (2006). The development of the field of HRD: a Delphi study. Journal of European Industrial Training, 30, 653-667.

McKenna, H.P. (1994). The Delphi technique: a worthwhile approach for nursing?. Journal of Advanced Nursing, 19, 1221-1225.

Miller, G. (2001). The development of indicators for sustainable tourism: results of a Delphi survey of tourism researchers. Tourism Management, 22, 351-362.

Mitchell, R.K., Agle, B.R., \& Wood D.J. (1997). Toward a Theory of Stakeholder Identification and Salience: Defining the Principle of Who and What Really Counts. Academy of Management Review, 22, 853-887.

Mudzamir, B.M., \& Norfaiezah, B.S. (2007). Corporate Social Responsibility (CSR) activities in mobile telecommunication industry: case study of Malaysia. European Critical Accounting Conference, Scotland, UK.

Mutula, S. M. (2008). Digital divide and economic development: case study of sub-Saharan Africa. The Electronic Library, 26, 468-489

Palazzi, M., \& Starcher, G. (2000). Corporate Social Responsibility and Business Success. Available: [Online] www.ebbf.org (15-10-2010)

Patten, D.M. (1991). Exposure, legitimacy, and social disclosure. Journal of Accounting and Public Policy, 10, 297-308.

Phillips, R. (2000). New applications for the Delphi technique, Annual "San Diego". Pfeiffer and Company, 2, 191-196

Plepys, A. (2002). The grey side of ICT. Environmental Impact Assessment Review, 22, 509-23.

Powell, C. (2003). The Delphi technique: Myths and realities. Journal of Advanced Nursing, 41, 376-382.

Runhaar, H., \& Lafferty, H. (2009). Governing Corporate Social Responsibility: An Assessment of the Contribution of the UN Global Compact to CSR Strategies in the Telecommunications Industry. Journal of Business Ethics, 84, 479-495.

Sachs, S., Maurer, M., Rühli, E., \& Hoffmann, R. (2006). Corporate Social Responsibility for a "stakeholder view" perspective: CSR implementation by a Swiss mobile telecommunication provider. Corporate Governance, 6, 506-15.

Salinas, R. (2003). Addressing the digital divide through collection development. Collection Building, 22, 131-6.

Schiebel, W., \& Pöchtrager, S. (2003). Corporate ethics as a factor for success - the measurement instrument of the University of Agricultural Sciences (BOKU), Vienna. Supply Chain Management: An International Journal, 8, 116-121.

Secchi, D. (2006). Corporate Social Responsibility in Europe: Analyzing Business in Transnational Contexts, in T. Palànkai (ed.), Adjusting to Enlargement, pp.83-101. Budapest: HECSA.

Simpson, G., \& Kohers, T. (2002). The link between corporate social and financial performance: Evidence from the banking industry. Journal of Business Ethics, 35, 97-109.

Skulmoski, G.J., Hartman, F.T., \& Krahn, J. (2007). The Delphi method for graduate research. Journal of Information Technology Education, 6, 1-21.

Spiller, R. (2000). Ethical business investment a model for business and society. Journal of Business Ethics, 27, 149-160.

Sturdivant, F., \& Ginter, J. (1977). Corporate social responsiveness, management attitudes and economic performance. California Management Review, 19, 30-39.

Sumsion, T. (1998). The Delphi technique: An adaptive research tool. British Journal of Occupational Therapy, 61, 153-156.

Sweeney L., \& Coughlan, J. (2008). Do different industries report Corporate Social Responsibility differently? An investigation through the lens of stakeholder theory. Journal of Marketing Communications, 14, 113-124. 
Talaei, G., \& Nejati, M. (2008). CORPORATE SOCIAL RESPONSIBILITY IN AUTO INDUSTRY: AN IRANIAN PERSPECTIVE. LESIJ.ES, XV, 1.

Thangaretinam, S., \& Redman C.W.E. (2005). The Delphi technique. The Obstetrician \& Gynaecologist, 7 , 120-125.

Turker, D. (2009). Measuring Corporate Social Responsibility: A Scale Development Study. Journal of Business Ethics, 85, 411-427.

Turoff, M. (1970). The design of a policy Delphi. Technological Forecasting and Social Change, 2, 149-71

United Nations, (2006). The digital divide report: ICT diffusion index 2005, United Nations Conference on trade and development, New York and Geneva. [Online] Available: www.unctad.org/en/docs/iteipc20065_en.pdf (19-11-2010)

Useem, M. (1988). Market and Institutional Factors in Corporate Contributions. California Management Review, $30,77-88$.

Vaccaro, A. (2006). Privacy, security, and transparency: ICT-Related Ethical Perspectives and Contrasts in Contemporary Firms. IFIP International Federation for Information Processing, 245-258.

Van Dijken, F. (2007). Corporate social responsibility: market regulation and the evidence. Managerial Law, 49, 141-184.

Vecchia, P. (2007). Scientific Rationale of ICNIRP Guidelines. WHO/ICNIRP/EMF-NET Joint Workshop on Current Trends in Health and Safety Risk Assessment of Work-Related Exposure to EMFs. Milan, Italy.

Werther, W.B., \& Chandler, D. (2005). Strategic corporate social responsibility as global brand insurance. Business Horizons, 48, 317-324.

Wild, C., \& Torgersen, H. (2000). Foresight in medicine: lessons from three European Delphi studies. European Journal of Public Health, 10, 114-119.

Williams, P.L., \& Webb, C. (1994). The Delphi technique: A methodological discussion. Journal of Advanced Nursing, 19, 180-186.

Wolfers, J., \& Zitzewitz, E. (2004). Five Open Questions about Prediction Markets. IZA Discussion Paper No. 1975. [Online] Available: http://ssrn.com/abstract=884483 (3-12-2010)

World Health Organization. (2000). Fact Sheet N193. [Online] Available: www.int/docstore/peh-emf/publications/facts_press/efact/efs193.html (19-11-2010)

World Health Organization. (2004). Electromagnetic Fields (EMF). Summary of health effects. [Online] Available: www.who.int/peh-emf/about/WhatisEMF/en/index1.html (16-11-2010)

World Summit on the Information Society. (2002). Why and how the environment has to be taken into account at the world summit on the information society, EPFL - Working Group on the impact of ICT on the Environment, Document WSIS/PC-2/CONTR/43-E.

Wright, D. (2005). The dark side of ambient intelligence. Info, 7, 33-51.

Yehle, L.C. (1996). US West communications and communication workers of America. Labor Arbitration, 107, 791-6. 
Table 1. CSR categories

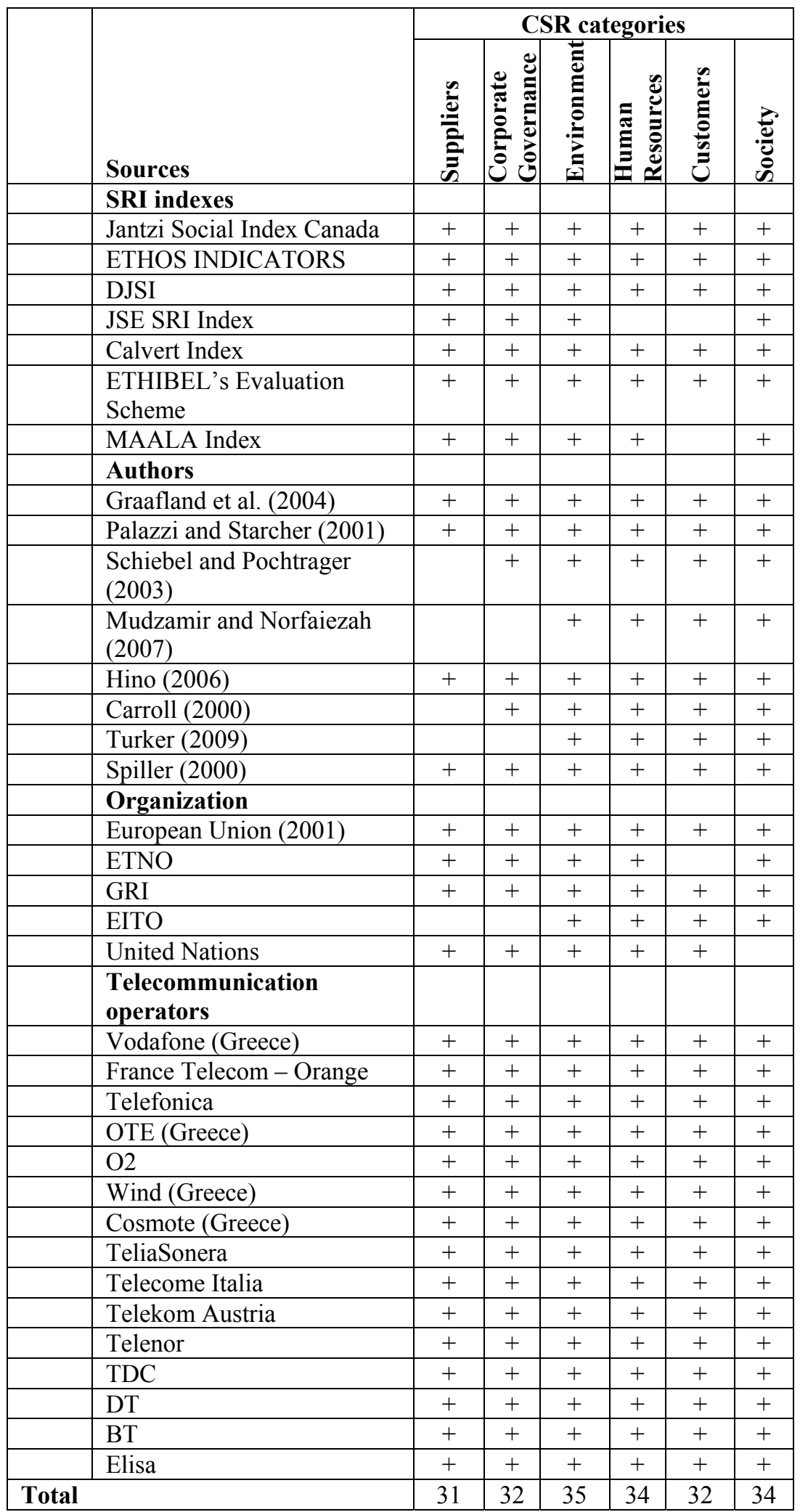


Table 2. Identified CSR indicators

\begin{tabular}{|c|c|c|}
\hline & CSR indicators & Companies \\
\hline & Environment & \\
\hline 1. & Programs of saving Natural sources and energy & 13 \\
\hline 2. & Recycling or reusing & 14 \\
\hline 3. & Electromagnetic radiation from telecommunication networks & 8 \\
\hline \multirow[t]{3}{*}{4.} & Responsible development of networks & 11 \\
\hline & Society & \\
\hline & Corporate Citizenship & \\
\hline 1. & Sponsorships & 13 \\
\hline 2. & Philanthropy & 15 \\
\hline 3. & Commitment to research programs & 11 \\
\hline 4. & Voluntary overtime & 8 \\
\hline \multirow[t]{2}{*}{5.} & Dialogue with stakeholders & 12 \\
\hline & Digital gap indicators & 15 \\
\hline 1. & Infrastructure development in low population density and/or remote areas & 5 \\
\hline 2. & Confirmation of proper function after emergency situations & 3 \\
\hline 3. & Equal access for groups with special needs & 6 \\
\hline 4. & Distribution of products/services in flexible prices & 5 \\
\hline \multirow[t]{2}{*}{5.} & Education or/and information of products and service advantages & 6 \\
\hline & Suppliers & \\
\hline 1. & Criteria selection & 12 \\
\hline 2. & Audits & 9 \\
\hline 3. & Collaboration & 9 \\
\hline 4. & Fulfillment of responsibilities correctly and timely & 4 \\
\hline \multirow[t]{2}{*}{5.} & Transparency & 6 \\
\hline & Customers & \\
\hline 1. & Responsible marketing & 10 \\
\hline 2. & Number of surveys satisfaction & 11 \\
\hline 3. & Responsible technology & 11 \\
\hline 4. & Customers' updating & 13 \\
\hline 5. & Service & 11 \\
\hline \multirow[t]{2}{*}{6.} & Quality & 13 \\
\hline & Human Resources & \\
\hline 1. & Health and Safety & 15 \\
\hline 2. & Equal opportunities & 12 \\
\hline 3. & Employees' Satisfaction & 13 \\
\hline 4. & Benefits-bonuses & 11 \\
\hline 5. & Training & 15 \\
\hline 6. & Personnel entertainment & 4 \\
\hline 7. & Assessment & 7 \\
\hline \multirow[t]{3}{*}{8.} & Flexible working programs & 10 \\
\hline & Corporate Governance & \\
\hline & CSR management & \\
\hline 1. & Weight of differentiation of stakeholders & 10 \\
\hline 2. & Assessment of CSR results & 12 \\
\hline 3. & Identification of Stakeholders expectations & 11 \\
\hline 4. & Risk assessment & 9 \\
\hline 5. & CSR transmission & 10 \\
\hline 6. & CSR in decision procedure & 4 \\
\hline \multirow[t]{2}{*}{7.} & Compliance with international standards and principles & 14 \\
\hline & Report & \\
\hline 1. & Publication of legislative offences or/and fines & 4 \\
\hline 2. & $\begin{array}{l}\text { Conclusions by internal or external stakeholders or organizations of CSR } \\
\text { report fulfillment }\end{array}$ & 7 \\
\hline 3. & Presentation of quantitative or comparable data & 13 \\
\hline
\end{tabular}


Table 3. Suppliers statistics

\begin{tabular}{|l|c|c|c|l|}
\hline Indicators & Mean & $\begin{array}{c}\text { Std. } \\
\text { Deviation }\end{array}$ & $\begin{array}{c}\text { Overall } \\
\text { Rank }\end{array}$ & \multicolumn{1}{|c|}{ Proposed Formula } \\
\hline Criteria selection & 2,0 & 1,4 & 1 & $\begin{array}{l}\text { Number of implementation of moral market } \\
\text { code }\end{array}$ \\
\hline Collaboration & 2,4 & 1,3 & 2 & $\begin{array}{l}\text { Number of meetings with suppliers for } \\
\text { quality issues }\end{array}$ \\
\hline Audits & 3,5 & 0,9 & 3 & Number of audits \\
\hline $\begin{array}{l}\text { Fulfillment of } \\
\text { responsibilities correctly and } \\
\text { timely }\end{array}$ & 3,5 & 1,4 & 4 & $\begin{array}{l}\text { Number of denunciations for the non } \\
\text { observance of responsibilities by the } \\
\text { suppliers }\end{array}$ \\
\hline \begin{tabular}{l} 
Transparency \\
\hline
\end{tabular} & 3,6 & 1,5 & 5 & $\begin{array}{l}\text { Number of published documents } \\
\text { concerning commercial relationships and } \\
\text { transactions }\end{array}$ \\
\hline
\end{tabular}

Table 4. Customers' statistics

\begin{tabular}{|l|c|c|c|l|}
\hline Indicators & Mean & $\begin{array}{c}\text { Std. } \\
\text { Deviation }\end{array}$ & $\begin{array}{c}\text { Overall } \\
\text { Rank }\end{array}$ & \multicolumn{1}{|c|}{ Proposed Formula } \\
\hline Responsible marketing & 2,1 & 1,1 & 1 & $\begin{array}{l}\text { Number of denunciations concerning } \\
\text { irresponsible juvenile marketing }\end{array}$ \\
\hline Service & 2,6 & 1,7 & 2 & Service satisfaction degree \\
\hline $\begin{array}{l}\text { Responsible } \\
\text { technology }\end{array}$ & 2,8 & 1,5 & 3 & $\begin{array}{l}\text { "Filter" of barring access to specific services } \\
\text { from juvenile }\end{array}$ \\
\hline Customers' update & 3,9 & 0,8 & 4 & $\begin{array}{l}\text { Provision of advice on security issues from the } \\
\text { official web site. }\end{array}$ \\
\hline Quality & 4,6 & 1,8 & 5 & Degree of customers' satisfaction \\
\hline $\begin{array}{l}\text { Number of satisfaction } \\
\text { surveys }\end{array}$ & 5,0 & 1,4 & 6 & Number of satisfaction surveys \\
\hline
\end{tabular}

Table 5. Human Resources statistics

\begin{tabular}{|c|c|c|c|c|}
\hline Indicators & Mean & $\begin{array}{c}\text { Std. } \\
\text { Deviation } \\
\end{array}$ & $\begin{array}{l}\text { Overall } \\
\text { Rank }\end{array}$ & Proposed Formula \\
\hline Health and Safety & 1,5 & 0,5 & 1 & $\begin{array}{l}\text { Number of monitoring in telecommunication } \\
\text { infrastructure concerning health and safety issues }\end{array}$ \\
\hline Equal opportunities & 2,4 & 2,0 & 2 & $\begin{array}{l}\text { Number of denunciations concerning } \\
\text { discrimination }\end{array}$ \\
\hline Training & 3,5 & 1,3 & 3 & Number of training hours \\
\hline Assessment & 4,5 & 1,5 & 4 & $\begin{array}{l}\text { (Number of employees participating in personnel } \\
\text { evaluation / Total number of personnel) } * 100\end{array}$ \\
\hline Benefits-bonuses & 4,6 & 1,3 & 5 & Total of bonus $(€)$ / Total number of personnel \\
\hline $\begin{array}{l}\text { Employees' } \\
\text { Satisfaction }\end{array}$ & 5,4 & 1,2 & 6 & $\begin{array}{l}\text { (Total number of personnel - number of personnel } \\
\text { resigned)/ (Total number of personnel)*100 }\end{array}$ \\
\hline $\begin{array}{l}\text { Personnel } \\
\text { entertainment }\end{array}$ & 6,8 & 1,7 & 7 & Number of entertainment occasions \\
\hline $\begin{array}{l}\text { Flexible working } \\
\text { programs }\end{array}$ & 7,5 & 1,1 & 8 & $\begin{array}{l}\text { (Number of employees participating in flexible } \\
\text { working programs / Total number of } \\
\text { personnel) }]^{* 100}\end{array}$ \\
\hline
\end{tabular}


Table 6. CSR management statistics

\begin{tabular}{|l|c|c|c|l|}
\hline Indicators & Mean & $\begin{array}{c}\text { Std. } \\
\text { Deviation }\end{array}$ & $\begin{array}{c}\text { Overall } \\
\text { Rank }\end{array}$ & \multicolumn{1}{|c|}{ Proposed Formula } \\
\hline $\begin{array}{l}\text { Compliance with } \\
\text { international standards } \\
\text { and principles }\end{array}$ & 2,9 & 2,6 & 1 & $\begin{array}{l}\text { Number of certifications (or } \\
\text { re-certifications) of international } \\
\text { standards of CSR such as GRI and } \\
\text { EMAS. }\end{array}$ \\
\hline $\begin{array}{l}\text { Weight differentiation } \\
\text { of stakeholders }\end{array}$ & 3,5 & 1,7 & 2 & $\begin{array}{l}\text { Differentiation of the weight of } \\
\text { stakeholders according to their } \\
\text { importance }\end{array}$ \\
\hline Risk management & 3,8 & 1,6 & 3 & $\begin{array}{l}\text { Recognition and evaluation of } \\
\text { possible dangers }\end{array}$ \\
\hline $\begin{array}{l}\text { Identification of } \\
\text { Stakeholders } \\
\text { expectations }\end{array}$ & 3,9 & 2,0 & 4 & $\begin{array}{l}\text { Number of strategic (important) } \\
\text { stakeholders whose expectations are } \\
\text { being recognized }\end{array}$ \\
\hline $\begin{array}{l}\text { CSR in decision } \\
\text { procedure }\end{array}$ & 4,0 & 2,3 & 5 & $\begin{array}{l}\text { Number of decisions where CSR is } \\
\text { taken into account }\end{array}$ \\
\hline $\begin{array}{l}\text { Assessment of CSR } \\
\text { results }\end{array}$ & 4,3 & 1,6 & 6 & $\begin{array}{l}\text { Number of assessment of CSR results } \\
\text { from external organizations }\end{array}$ \\
\hline CSR transmission & 5,8 & 1,8 & 7 & $\begin{array}{l}\text { Number of practices adopted by } \\
\text { suppliers }\end{array}$ \\
\hline
\end{tabular}

Table 7. Report statistics

\begin{tabular}{|l|c|c|c|l|}
\hline Indicators & Mean & $\begin{array}{c}\text { Std. } \\
\text { Deviation }\end{array}$ & $\begin{array}{c}\text { Overall } \\
\text { Rank }\end{array}$ & \multicolumn{1}{|c|}{ Proposed Formula } \\
\hline $\begin{array}{l}\text { Presentation of quantitative or } \\
\text { comparable data }\end{array}$ & 1,4 & 0,7 & 1 & $\begin{array}{l}\text { Number of published indicators on } \\
\text { basic CSR practices }\end{array}$ \\
\hline $\begin{array}{l}\text { Publication of legislative offences } \\
\text { or/and fines }\end{array}$ & 2,3 & 0,9 & 2 & $\begin{array}{l}\text { Publication of legislative offences } \\
\text { or/and fines }\end{array}$ \\
\hline $\begin{array}{l}\text { Conclusions by internal or external } \\
\text { stakeholders or organizations for the } \\
\text { completeness of CSR report }\end{array}$ & 2,4 & 0,5 & 3 & $\begin{array}{l}\text { Publications of the report by external } \\
\text { (audit) organization company for the } \\
\text { completeness of CSR report }\end{array}$ \\
\hline
\end{tabular}

Table 8. Corporate Citizenship statistics

\begin{tabular}{|l|c|c|c|l|}
\hline Indicators & Mean & $\begin{array}{c}\text { Std. } \\
\text { Deviation }\end{array}$ & $\begin{array}{c}\text { Overall } \\
\text { Rank }\end{array}$ & \multicolumn{1}{|c|}{ Proposed Formula } \\
\hline Philanthropy & 2,8 & 1,6 & 1 & Total of charities $(€) /$ total revenues \\
\hline Voluntary programs & 2,8 & 1,6 & 1 & $\begin{array}{l}\text { Sum of occupational hours of the } \\
\text { personnel in social projects }\end{array}$ \\
\hline $\begin{array}{l}\text { Commitment to } \\
\text { research programs }\end{array}$ & 3,0 & 1,6 & 3 & $\begin{array}{l}\text { Number of research programs } \\
\text { concerning technological } \\
\text { improvements }\end{array}$ \\
\hline $\begin{array}{l}\text { Dialogue with } \\
\text { stakeholders }\end{array}$ & 3,0 & 1,2 & 4 & $\begin{array}{l}\text { Number of meetings with } \\
\text { stakeholders }\end{array}$ \\
\hline Sponsorships & 3,5 & 1,4 & 5 & $\begin{array}{l}\text { Total of sponsorships }(€) / \text { total } \\
\text { revenue }\end{array}$ \\
\hline
\end{tabular}


Table 9. Digital Divide statistics

\begin{tabular}{|l|c|c|c|l|}
\hline Indicators & Mean & $\begin{array}{c}\text { Std. } \\
\text { Deviation }\end{array}$ & $\begin{array}{c}\text { Overall } \\
\text { Rank }\end{array}$ & \multicolumn{1}{|c|}{ Proposed Formula } \\
\hline $\begin{array}{l}\text { Infrastructure development in } \\
\text { low population density and/or } \\
\text { remote areas }\end{array}$ & 2,0 & 1,4 & 1 & $\begin{array}{l}\text { [Square kilometers of service coverage } \\
\text { /total of square kilometers of coverage } \\
* 100\end{array}$ \\
\hline $\begin{array}{l}\text { Confirmation of proper } \\
\text { function after emergency } \\
\text { situations }\end{array}$ & 2,8 & 1,5 & 2 & $\begin{array}{l}\text { Restoration time of proper service } \\
\text { function after emergency situations }\end{array}$ \\
\hline $\begin{array}{l}\text { Equal access to groups with } \\
\text { special needs }\end{array}$ & 3,0 & 1,1 & 3 & $\begin{array}{l}\text { Number of services concerning special } \\
\text { groups }\end{array}$ \\
\hline $\begin{array}{l}\text { Education on the benefits of } \\
\text { products and/or services }\end{array}$ & 3,1 & 1,5 & 4 & $\begin{array}{l}\text { Number of actions on the education or } \\
\text { familiarization of the citizens with the } \\
\text { telecommunication services }\end{array}$ \\
\hline $\begin{array}{l}\text { Free product/service } \\
\text { distribution in flexible prices }\end{array}$ & 4,1 & 1,1 & 5 & Value (€) of freely distributed services \\
\hline
\end{tabular}

Table 10. Environment statistics

\begin{tabular}{|l|c|c|c|l|}
\hline Indicators & Mean & $\begin{array}{c}\text { Std. } \\
\text { Deviation }\end{array}$ & $\begin{array}{c}\text { Overall } \\
\text { Rank }\end{array}$ & \multicolumn{1}{c|}{ Proposed Formula } \\
\hline $\begin{array}{l}\text { Electromagnetic radiation } \\
\text { from telecommunication } \\
\text { networks }\end{array}$ & 2,4 & 1,2 & 1 & $\begin{array}{l}\text { Stricter limits than those defined by the law of } \\
\text { international organizations regarding the } \\
\text { electromagnetic radiation }\end{array}$ \\
\hline Recycling or reusing & 2,5 & 1,1 & 2 & $\begin{array}{l}\text { Amount of recycling or reusing office material / } \\
\text { amount of used office material }\end{array}$ \\
\hline $\begin{array}{l}\text { Responsible development } \\
\text { of networks }\end{array}$ & 2,5 & 1,3 & 3 & $\begin{array}{l}\text { Number of common telecommunication } \\
\text { infrastructure with other providers / total } \\
\text { number of telecommunication infrastructure }\end{array}$ \\
\hline $\begin{array}{l}\text { Saving programs of } \\
\text { Natural sources and } \\
\text { energy }\end{array}$ & 2,6 & 1,2 & 4 & $\begin{array}{l}\text { [MWh consumption of telecommunication } \\
\text { infrastructure (t) - MWh consumption of } \\
\text { telecommunication infrastructure }(\mathrm{t}-1)]\} / \mathrm{MWh} \\
\text { consumption of telecommunication } \\
\text { infrastructure (t-1) }\}^{*} 100\end{array}$ \\
\hline
\end{tabular}

Figure 1. A value tree of CSR aggregate index 